\title{
Editorial RES 2/2015
}

Die meisten Aufsätze in dieser Nummer von RES gehen auf Vorträge zurück, die auf einer internationalen Konferenz mit dem Titel „Theology of the Holy Spirit: personal experience and charismatic movements in contemporary churches" gehalten wurden. Diese Konferenz wurde vom 12.-15. November in Hermannstadt durchgeführt, in Zusammenarbeit mit ICCO - Kerk in Actie aus den Niederlanden und dem Biblischen Institut St. Andrews in Moskau. In den Beiträgen kommen verschiedene Aspekte zur Sprache, die mit der Rolle des Heiligen Geistes in den christlichen Gemeinschaften zusammenhängen - sei es in traditionellen Kirchen, sei es in neuen pfingstlichen oder charismatischen Gemeinden.

Unter Bezugnahme auf Hildegard von Bingen und Martin Luther ging es Olga Zaprometova darum, den "Glauben des Herzens" zu beschreiben, womit nicht so sehr ein bestimmtes Verständnis von Gott gemeint ist, sondern dessen wahrhaftige, heilige Gegenwart. Die Autorin versucht, Begriffe zu klären und so zu einem wechselseitigen Verstehen der unterschiedlichen Ansätze zu gelangen, was den Heiligen Geist betrifft.

Nikolaos Asproulis fasst die orthodoxe Sicht bezüglich Person und Werk des Heiligen Geistes in der Kir-
Most of the studies gathered in this issue of RES were originally presented at the international conference held between 12-15 November in Sibiu under the title "Theology of the Holy Spirit: Personal Experience and Charismatic Movements in Contemporary Churches". The conference was organized by RES in collaboration with ICCO - Kerk in Actie, The Netherlands, and St Andrew's Biblical Theological Institute, Moskow, Russia. The studies discuss different aspects relating to the work of the Holy Spirit in Christian communities belonging to traditional Churches as well as in those that are part of the new Charismatic and Pentecostal Churches.

By turning to Hildegard of Bingen and to Martin Luther for a better understanding of the concept of "faith of the heart", Olga Zaprometova's study aims to emphasize faith not just as a matter of understanding God, but also as experiencing the real presence of the Holy One. A particular focus is on clarifying terms and on trying to further an understanding of diverse positions on the issue of the Holy Spirit.

Nikolaos Asproulis summarizes the Orthodox view about the person and the work of the Holy Spirit 
che und der Welt zusammen und legt dabei den Schwerpunkt nicht so sehr auf die liturgisch-sakramentale, sondern vielmehr auf die soziale und politische Dimension. Es ist eine herausfordernde Stellungnahme, worin die Frage diskutiert wird, in welcher Beziehung der orthodoxe dogmatische ,Traditionalismus' zur gegenwärtigen (post-) modernen Welt steht.

Ein weiterer orthodoxer Beitrag stammt von Kseniya Bobkova, die das Problem diskutiert, welche Stellung der Heilige Geist in orthodoxen ekklesiologischen Entwürfen des 20. Jhd. einnimmt. Sie bezieht sich vor allem auf die eucharistische Ekklesiologie von Nikolaj Afanasiev, der ähnlich wie andere gegenwärtige orthodoxe Theologen (Sergej Bulgakov, Georges Florovsky, Vladimir Lossky, Alexander Schmemann und John Zizioulas) den engen Zusammenhang zwischen Pneumatologie und Christologie herausstrich. Die Wirklichkeit der Kirche - und damit auch der Sakramente, im Besonderen der Eucharistie, als deren Zentrum - kann nur adäquat verstanden werden, wenn sie in die Beziehung zwischen Jesus Christus und dem Heiligen Geist, den beiden ,Händen des Vaters' (Irenäus), eingezeichnet wird.

Timothy Lim stellt die Frage nach einer pneumatologischen Ekklesiologie, auf dem Hintergrund der Metapher von den beiden „Lungenflügeln“ der Kirche, die im Dialog zwischen römisch-katholischer und orthodoxer Theologie gerne verwendet wird. Inso- in the Church and in the world, focusing not so much on the liturgical-sacramental dimension, but on the social-political one. It is a challenging study, which raises the question of Orthodox dogmatic "traditionalism" in relation to the contemporary (post)modern world.

Kseniya Bobkova, also writing from an Orthodox perspective, describes the role played by the Person of the Holy Spirit in $20^{\text {th }}$ century Orthodox ecclesiology. She cites the Eucharistic ecclesiology of Nicholas Afanasiev; like other contemporary Orthodox theologians (Sergei Bulgakov, Georges Florovsky, Vladimir Lossky, Alexander Schmemann, or Metropolitan John Zizioulas), he views pneumatology as inextricably linked to Christology and states that the reality of the Church, with the sacraments and especially the Eucharist as central elements, can only be properly understood through the relationship between Jesus Christ and the Holy Spirit, the "two hands" of the Father (St. Irenaeus).

In an ample study, Timothy Lim attempts to develop a pneumatological ecclesiology. For his starting point, he takes the metaphor "two lungs of the church", which appears in the dialogue between Orthodox and Roman Catholic theologians. However, the two lungs metaphor of the Spirit's work in the Orthodox and Catholic tradi- 
weit sich diese Metapher auf das Werk des Heiligen Geistes in orthodoxer und katholischer Tradition bezieht, trägt sie die unbeabsichtigterweise die Tendenz in sich, protestantische Gemeinschaften (besonders die neueren) aus dieser Ökumene der Kirchen auszuschliessen. Der Autor stellt darum die Frage nach einer ,alternativen Metapher', die das universale Wirken des Geistes, des Spenders allen Lebens, besser ausdrückt.

Die folgenden beiden Beiträge stammen von jüngeren pfingstkirchlichen Autoren aus Rumänien. Dragos S, Stefanică bietet eine vergleichende Übersicht über das Verständnis der Charismata, der Gaben des Heiligen Geistes, in verschiedenen christlichen Traditionen. Der Autor kommt zum Schluss, dass die Defintion in der katholischen, orthodoxen und reformierten Theologie jeweils sehr breit ist, während sie in der pfingstkirchlichen Tradition eine schmalere, spezifische Bedeutung hat. $\mathrm{Zu}$ dieser Frage ist ein tiefergehender Dialog notwendig. Eugen Jugaru diskutiert zwei Punkte aus der pfingstkirchlichen Dogmatik: die Taufe im Heiligen Geist und die Gabe der Prophetie. Um dies herauszuarbeiten, macht er einen Vergleich mit der evangelikalen Perspektive auf diese Fragen, wobei Gemeinsamkeiten und Unterschiede zum Ausdruck kommen. Trotz mancher lehrmässiger Berührungspunkte hat die pentekostale Theologie doch ihre eigenen Akzente und ruft zu einer Neuentdeckung der Taufe im Heiligen Geist und der Pro- tions has unwittingly proven to be exclusionary and alienated younger, newer Protestant communities from Christian ecumenicity. In conclusion, the author asks if one needs an alternative metaphor, encompassing more conclusively the universal work of the Holy Spirit, since it breathes life.

The next two studies are authored by Dragos, Stefanică and Eugen Jugaru, two young Romanian Pentecostal theologians. Ștefanică provides a comparative presentation of the charismata, or the gifts of the Holy Spirit in various Christian traditions. The author concludes that the definitions formulated by Catholic, Eastern Orthodox, or Reformed theologies are very broad, while in Pentecostal theology charismata have a rather technical meaning; therefore, there is a need to continue the inter-Christian dialogue on the subject. Jugaru provides a short presentation on the Pentecostal understanding of two of its foundational doctrines: baptism in the Holy Spirit and the gift of prophecy. For a better understanding, reference is made to the Evangelical concept, focusing both on the common points but also on differences. In spite of many doctrinal communalities with Evangelical theology, Pentecostal theology is distinguished by its call for the rediscovery of baptism in the Spirit and the gift of prophecy. 
phetie auf, Zeichen einer lebendigen Kirche der Gegenwart.

Der Aufsatz von Marina Kazmiruk ist eine der seltenen Beschreibungen von charismatischen Bewegungen im Bereich der früheren Sowjetunion. Sie analysiert Beispiele von charismatischen Gemeinschaften in Weissrussland, die teils von ekstatischen Ausdrucksformen des Glaubens geprägt sind. Entstehung, Wachstum und spezifische Kennzeichen dieser Gruppen werden beschrieben und dabei ein Bild von der 'katholischen Erneuerung' auf dem Gebiet von Weissrussland gezeichnet.

Als Essay ist ein Beitrag von Wilbert van Iperen aufgenommen. Er bezieht sich auf den so genannten "Evangelisch Werkverband" innerhalb der Protestantischen Kirche in den Niederlanden, der 1995 gegründet wurde. Der Autor möchte auf zwei Fragen Antwort geben: wie reagieren traditionelle Kirchen auf charismatische Aufbrüche in ihren eigenen Reihen? Wie verhalten sich charismatische Bewegungen zur Kirche, zu der sie gehören?

All diese Einzelstudien gehören in den Zusammenhang einer grossen Frage: ist es möglich, die traditionelle Lehre vom Heiligen Geist mit der Erfahrung innerhalb der pentekostalen und charismatischen Bewegungen zu verbinden und zu versöhnen? Welche Relevanz hat die Antwort auf diese Frage für alle, die an einer Theologie des Heiligen Geistes arbeiten - seien es Kleriker, Theologen oder Laien? An sie richtet sich diese Nummer von RES.
The study written by Maryna Kazmiruk is one of the very few descriptions of the charismatic movement in the former Soviet Union, more specifically in Belarus. Her analysis of ecstatic charismatic communities in Belarus focuses on the formation and the growth of these groups, as well as on the characteristics and development of the Catholic "renewal movement" in Belarus.

In his contribution, Wilbert van Iperen discusses the "Evangelischer Werkverband" movement, which started its activities in 1995. More specifically, the author seeks to answer some questions, such as: How do traditional churches relate to charismatic movements in their midst? How do charismatic movements relate to the Church they belong to? Is it possible to reconcile the traditional Church teaching about the Holy Spirit with the experience of the Spirit in Pentecostalism and charismatic movements? Are charismatic movements relevant for all those who try to elaborate a theology of the Holy Spirit - clergy, theologians, and ordinary believers? This issue of RES is primarily addressed to them.
Stefan Tobler Aurel Pavel 